\title{
Efficacy of Bee Honey on Wound Healing: Split Skin Graft with Hyper-granulation Tissue
}

\author{
Mahasin Wadi ${ }^{{ }^{*}}$ and Talal Geregandi ${ }^{2}$ \\ ${ }^{1}$ Medical Microbiology, Princess Nourah Bint Abdulrahman University, College of Nursing, Department of \\ Medical Surgical, Riyadh, Saudi Arabia; mahasinwadi@yahoo.com \\ ${ }^{2}$ Clinical Surgery, MD Plastic Surgery and Reconstructive Surgery, Khartoum North Teaching Hospital, \\ Surgery and Plastic Surgery Unit, Khartoum, Sudan; t_geregandi@yahoo.com
}

\section{Abstract}

The present prospective study was aimed to evaluate the effectiveness of topical application of bee honey on wound healing with hyper granulation tissue of infected split skin graft. Methods: A 27 years old female was admitted to Khartoum North Teaching Hospital plastic surgery unit with painful swelling of the right buttock with localized heat, which was proved as a pyogenic abscess. Swabs were taken from the wound for isolation, identification and viable bacterial count. The abscess was drained under general anesthesia and dressed with saline and MEBO ointment (combination of honey and herbs). Skin graft was performed. After 2 weeks of MEBO dressing, the wound was infected and hyper granulation tissue was observed. Daily application of honey was used instead of MEBO ointment. Results: Isolated organism was identified as Staphylococcus aureus. In vitro antibacterial test of honey against the isolated organism exhibited strong antibacterial activity. After one week of honey dressing, bacterial growth was inhibited and finally the wound was free from S. aureus. After 2 weeks of honey dressing, wound healing with reduced, hyper- granulation tissue was found. Conclusion: Topical application of honey dressing on wound with hyper granulation tissue for 3 weeks resulted in clean sterile wound with healthy granulation tissue and prompt graft was observed. Complete wound healing was achieved and hyper granulation tissue was reduced without surgical interference.

Keywords: Honey Dressing, Split Skin Graft with Hyper-granulation Tissue, Wound Healing

\section{Introduction}

The formation of persistent granulation tissue, also known as hyper granulation tissue, or hypertrophic granulation, is a complication of surgical wound healing. Hyper granulation tissue fills beyond the height of the wound and prevents keratinocyte migration from wound edges to complete epithelialization ${ }^{1}$. It presents as exophytic, erythematous, and friable tissue ${ }^{2}$. Histologically, it appears as pyogenic granuloma with an increase in fibroblasts and endothelial cells ${ }^{3}$. Treatment of the tissue can be managed by chemical cautery with silver nitrate or topic corticosteroids to help epithelialization and migration of keratinocytes from the wound edges leading to wound healing process ${ }^{4,5}$.
The process of tissue repair depends on the tissue response to injury ${ }^{6}$. Wound healing can be affected by changes in $\mathrm{pH}$ at every phase $\mathrm{e}^{7,8}$. Previous findings confirmed that the $\mathrm{pH}$ of a chronic wound was evaluated in the range of $7.15-8.9^{7,9,10}$. Wound healing is a normal process of biological event, that occurs. Wound healing process includes hemostasis, different inflammation process, proliferation, and remodeling ${ }^{2,11}$ One of the effective healing factors is the $\mathrm{pH}$, different $\mathrm{pH}$ ranges are required for the different phases of wound healing ${ }^{12}$.

Measurements of wound healing and progression may provide a more accurate way of assessing throughout treatment and is considered useful in routine clinical wound care $^{2}$. A numbers of topical preparations and dressings have been developed to

\section{*Author for correspondence}


control or mange wound healing. Different products like pH-modulating dressing, controlled carbon dioxide loss from tissue are used for preventing respiratory alkalosis ${ }^{2,7,13}$. Uses of Bee Honey, and acidified nitrate creams, initiate acidification of the wound bed and have been found to help in the healing of the wound and also inhibit microbial infections ${ }^{14,15}$. Therapeutic uses of honey have been documented in improving wound healing including antimicrobial activity and stimulation of heathy granulation tissue ${ }^{16}$. Honey dressing was found to be effective in the healing of chronic infected wounds that do not respond to the conventional antibiotics treatment ${ }^{17}$. Different honey concentrations have been studied against Gram -positive and Gram negative organisms. It was found that honey is effective bactericidal agent at wide range against both organisms ${ }^{18}$. Topical application of manuka honey was found to be effective and achieved $\geq 80 \%$ wound contraction in both the nondiabetic and diabetic group ${ }^{19}$.

Previous findings confirmed that a key factor in the efficacy of honey is its low $\mathrm{pH}$ between 3 to $4^{20}$. Nitric oxide is continually released from normal skin and has antimicrobial effects; that protects the skin from infection ${ }^{2}$. Methanol extraction of honey results in three fractions, one of the fractions along with whole honey, showed a good antibacterial effect against pathogens like E. coli, Klebsiella, Staphylococcus albus, Staphylococcus aureus, in contrast the other fraction showed no antibacterial activity against Pseudomonas ${ }^{21}$. Honey was found to be highly effective on the tested organisms of MRSA isolates with MIC and MBC ranging from 9.38$37.5 \% \mathrm{v} / \mathrm{v}^{22}$. Croatian honey, prominently honeydew honey, has been reported for its the very effective antibacterial activity and its potential to become an important additive to therapeutic techniques available to a medical practitioner against resistant pathogens ${ }^{23}$. Honey film has a greater effectiveness to accelerate the healing of burns and incision wounds when compared to the negative control ${ }^{24}$. Combination of propolis and honey on the open wound in rats it has a synergistic effect on wound healing ${ }^{25}$.

Honey has been reported to reduce inflammation ${ }^{26}$, edema and exudation ${ }^{27}$. A comparative study confirmed that Sidr honey is effective in dressing of second-intention healing of full-thickness infective skin wounds in dogs. Wounds treated by Sidr honey healed faster as compared with iodine dressing. Topical application of Sidr honey is an excellent dressing for wound infected with MRSA without any side effects ${ }^{28}$.Topical application of Sidr honey is an excellent alternative for wound infected with MRSA without any concern of systemic side effects ${ }^{29}$. Raw unprocessed honey is a good, simple and effective solution for eradication of biofilms and enhances healing in non-healing ulcers ${ }^{30}$.

The aim of the present study was to evaluate the healing effect of honey dressing on infected wound with hyper granulation tissue of split skin graft.

\section{Materials and Methods}

A 27 years old female was admitted to Khartoum North Teaching Hospital, Sudan. Surgery and plastic surgery unit during February -March 2018 with enlarged swelling, area about $10-13 \mathrm{~cm}$ in diameter red and tender located in the upper lateral quadrant of the right buttock, gluteal region, with localized heat, and pain. It was grafted one month ago. Excessive granulation tissue was observed. There were only mild generalized symptoms, with elevation of body temperature to $38.2{ }^{\circ} \mathrm{C}$. Swabs were taken from the wound surface for isolation, identification and viable bacterial count. The abscess was drained under general anesthesia and dressed with saline and MEBO (ointment combination of honey and herbs), for 2 weeks. Clean wound was obtained and skin graft was performed. Dressing was changed to saline and topical application of pure sterile honey. Weekly culture swabs were monitored during the initial phase of treatment. Wounds were observed twice a day during the first week and once daily for the rest till healing was obtained. Observation was undertaken by taking swabs for bacterial count. Wounds were checked for the presence of any signs of inflammation such as hyperemia, edema, and degree of exudation and type of granulation tissue. Follow up of wound was assessed by viable bacterial count, wound size, exudate, level and type of granulation tissue and digital photography of the wound were taken. 


\subsection{Honey Samples}

Natural sterile un processed honey sample supplied from the apiary was used for topical application of infected wound. Honey sample was stored in sterile glass container at room temperature. Sample was labeled according to the source, location, $\mathrm{pH}$, and date of collection. Honey sample was checked for sterility by conventional microbiological methods in Microbiology Laboratory.

\subsection{Clinical Isolates}

Sterile swabs were used for collecting clinical specimens before during and after wound dressing for identification, viable count and sensitivity test.

\subsection{Culture Media}

The following culture media were used for isolation, identification and viable count of the causative organism.

- Blood Agar (Oxoid).

- Blood Agar Base (Oxoid) (pH 7.2).

- Cystine Lactose Electrolyte Deficient(Oxoid)

- DNASE Agar Mast (Oxoid) pH 7.3.

- Mac Conkey Agar No. 3 (Oxoid) pH7.1.

- MacConkey Agar (Pronadisa).

- Mannitol Salt Agar (LAMB).

- Muller Hinton Agar (Biolife).

- Muller Hinton Broth (LABM) pH $7.4 \pm 0.2$.

- Nutrient Agar (Pronadisa) pH 6.8.

\subsection{In vitro Antibacterial Activity of Bee Honey}

\subsubsection{Inoculum Preparation}

Pure culture and standard inoculum size was maintained for antibacterial susceptibility. Test and control organisms were suspended in a sterile saline to match 0.5 McFarland standard tube, which is commercially available, provide an optical density of $1.5 \times 10^{8}$ colony forming units $(\mathrm{CFU} / \mathrm{ml})$. The well plate technique was used for testing honey antibacterial activity due to it is high viscosity ${ }^{31}$.

\subsubsection{Well Plate Technique}

The standard seeded agar diffusion technique was used ${ }^{32}$. Muller Hinton agar used as the culture medium, was reconstituted, sterilized (using autoclave) at $121^{\circ} \mathrm{C}$ for 15 minutes allowed to cool at $48^{\circ} \mathrm{C}$ and inoculated with $0.1 \mathrm{ml}$ of standardized 24 broth culture of bacterial suspensions that matched the turbidity of the $0.5 \mathrm{McF}$ arland standard tube $\left(1.5 \times 10^{8}\right)(\mathrm{FU} / \mathrm{ml})$. The isolated organisms were used, for antimicrobial susceptibility testing. Standard antibacterial test published by the National Committee for clinical laboratory standards was adopted. The seeded medium was distributed aseptically in $20 \mathrm{ml}$ into sterile Petri-dishes (95 mm internal diameter) and allowed to solidified. The solidified inoculated agar plate was then stored at $4^{\circ} \mathrm{C}$. Four wells ( $8 \mathrm{~mm}$ diameter) were cut using $8 \mathrm{~mm}$ sterile cork borer, and the cut-disc of agar were removed. $0.2 \mathrm{ml}$ of honey sample was carefully added. Inoculated plates were incubated at $37^{\circ} \mathrm{C}$ for $18-24$ hours. The diameter of inhibition zone was measured in $(\mathrm{mm})$. Honey sample was tested against each organism in four replicate and expressed as mean values.

\section{Results}

Unprocessed honey sample was tested for sterility at Microbiology Laboratory and was proved to be sterile without bacterial growth.

A 27 years old female was admitted to Khartoum North Teaching Hospital, surgery and plastic surgery unit with pyogenic abscess. The lesion was proved as pyogenic abscess in the upper lateral quadrant of the right buttock and was $10-13 \mathrm{~cm}$ in diameter, with redness and localized heat. The isolated organism was identified as Staphylococcus aureus according to the conventional microbiological tests. The isolated organism was found to be sensitive to the tested honey samples ( $27 \mathrm{~mm}$ diameter of inhibition zone).

The abscess was drained under general anesthesia. After 2 weeks of MEBO (Ointment) dressing, the wound became infected and hyper granulation tissue was noted, (Figure 1).

After one week of honey dressing the hyper granulation tissue was reduced to the level of the skin graft (Figure 2). 


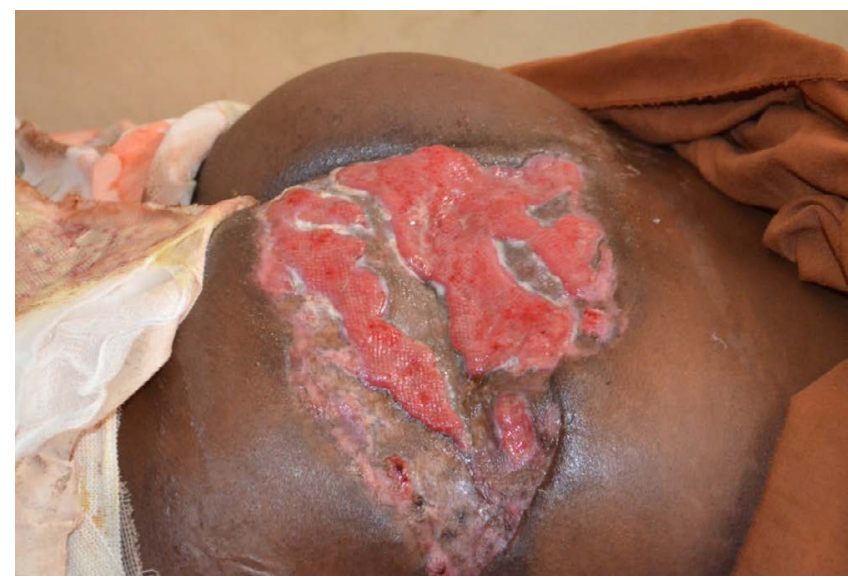

Figure 1. Wound after 2 weeks of MEBO dressing the wound became infected (split skin graft), and hyper granulation was noted.

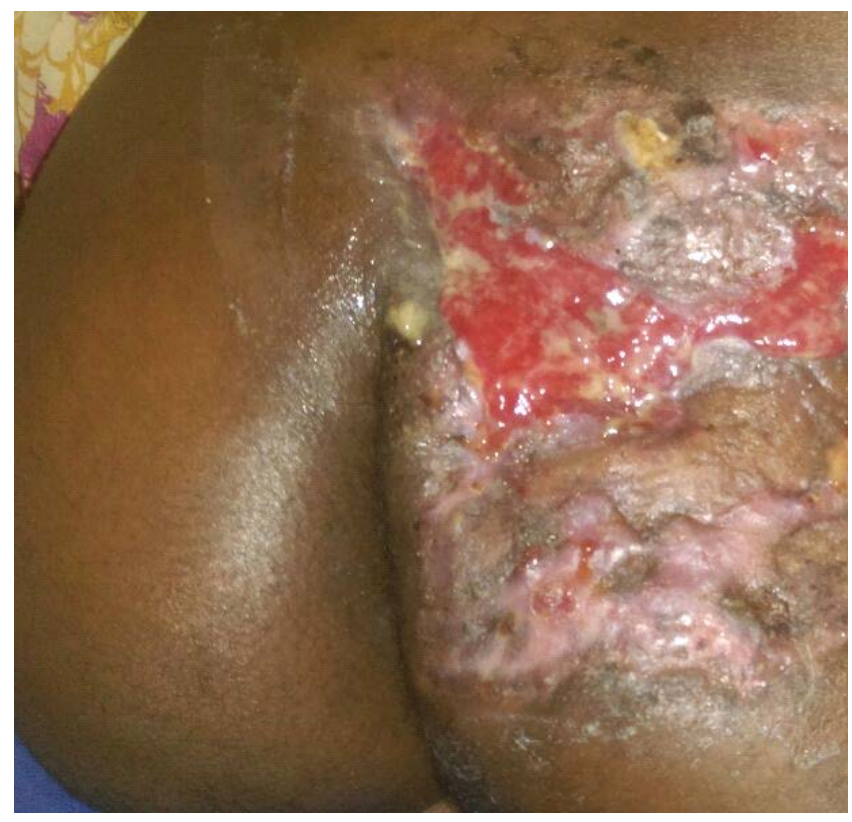

Figure 2. Wound after one week of honey dressing, wound size was reduced hyper granulation tissue was reduced to the level of the skin graft.

Wound was decreased in size. Bacterial viable count was decreased in numbers and the tissue appears as bright, healthy and normal granulation tissue. Honey dressing after 2 weeks resulted in healthy granulation tissue, sterile wound and reduction of the hyper granulation tissue. The isolated swabs showed no bacterial growth. Wound size was decreased (Figure 3).

After 3 weeks of honey application full epithelization was achieved and reduced hyper granulation tissue

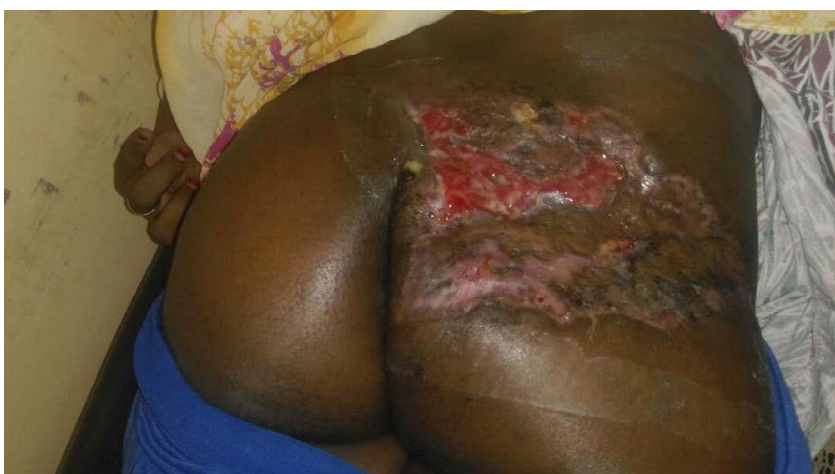

Figure 3. After 2 weeks of honey dressing, sterile wound with healthy granulation tissue was obtained.

was observed, complete wound healing was achieved without surgical interference and without side effects (Figure 4).

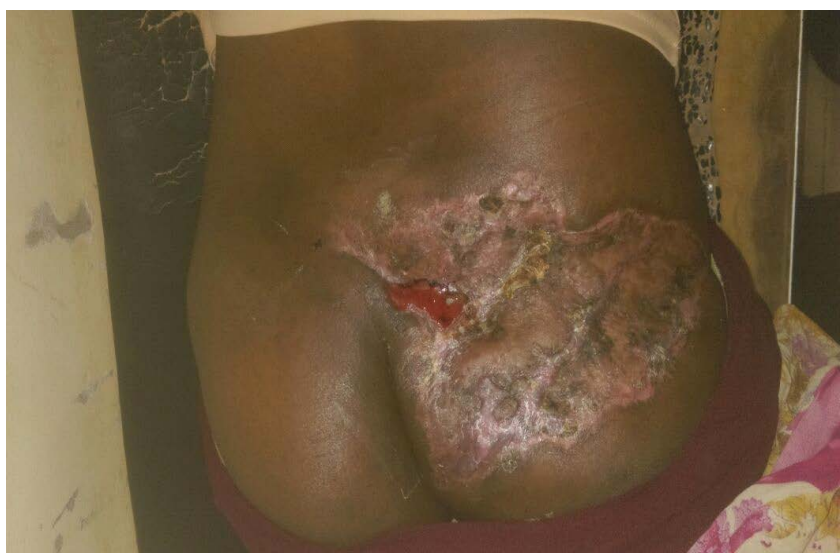

Figure 4. After 3 weeks of honey application full epithelization and healing of the wound was achieved and reduced hyper granulation tissue was obtained.

\section{Discussion}

A 27 years old female with pyogenic abscess of the right buttocks was drained under general anesthesia. Wound was cleaned and dressed twice a week with saline and MEBO ointment. Wound was grafted by split skin graft. Sterile wound with healthy granulation tissue was obtained. Split skin graft was performed to cover the large debrided opened wound. After 2 weeks of MEBO ointment dressing, the wound was infected and hyper granulation tissue was observed. Hypergranulation tissue appeared uneven and was raised from the base of the wound bed. The isolated organism was identified 
as Staphylococcus aureus. Hypergranulation tissue impaired wound healing. Wound was cleaned and dressed daily with honey instead of MEBO. After one week of honey dressing sterile wound was obtained. Hypergranulation tissue prevented epithelialization and the healing process was arrested. Honey dressing resulted in reduction of granulation tissue level and the bacterial count was decreased in numbers. Conventional treatment regimens of hypergranulation tissue is silver nitrate, a caustic technique that is extremely destructive, and when activated, will oxidise organic matter, coagulate tissue and destroy bacteria; tissue $^{15}$. Initial debridement of the hypergranulation tissue can take the form of dry swab wipe removal, sharp debridement or curettage or silver nitrate ${ }^{5}$. After 2 weeks of honey dressing wound became sterile, the hypergranulation tissue was reduced to the wound level, and wound size was decreased and helped graft taking without surgical interference.

Surgical or sharp debridement of the area was extremely successful at removing the hypegranulation tissue, but not successful at preventing recurrence ${ }^{5}$. Clinical study showed the beneficial effect of honey in promoting wound healing and reduced wound area, induced earlier granulation tissue formation. It is suggested that honey modulates the wound healing process $^{33,34}$. Honey as a wound dressing has been shown to be effective on different wound types ${ }^{35}$.

Our result showed that honey improved hypergranulation tissue formation to the wound level without surgical interference. Honey exhibited strong antibacterial activity resulted in sterile wound which helped in wound healing in short duration as compared with the conventional dressing.

The antibacterial activity of honey has been attributed to its impact on the healing process of chronic wounds. Honey has been proved to eliminate different organisms from wounds and provides sterile moist environment for wound healing. In vitro antibacterial activity of honey has been proved. Research has also focused on identifying the immunomodulatory effects of honey ${ }^{36,37}$.

Our experience with honey dressing showed favorable results that honey act as anti-inflammatory agent and might be superior to some conventional dressing materials. Honey exhibited potent multiple anti-inflammatory effects. Clinically, there have been numerous observations reported of honey reducing edema and exudate, minimizing scarring and having a soothing effect when applied to inflamed wounds and burns ${ }^{37}$. Honey is effective to limit the growth of wound pathogens, but also there is evidence that honey has the potential to promote the wound healing ${ }^{38}$. Honey has been reported to heal infected post-operative wounds more quickly than antiseptics and gauze ${ }^{39}$.

In the present study daily application of honey to the infected wound accelerated wound healing without hypergranulation. In addition, our present in vitro findings have shown powerful antibacterial activity of honey against the isolated organism. This in line with the previous findings that the low $\mathrm{pH} 3$ of honey helped to accelerate healing process ${ }^{20}$. Honey is a natural product can be used for wound dressing without complications. Honey was found to be more effective when compared with the conventional dressing. These present findings are in line with the previous findings, that resulted in a clean healthy granulation appearance that was typical of each wound in the twelve of their patients who had undergone radical vulvectomy ${ }^{39}$. The effectiveness of honey was attributed to its antibacterial activity and promotion of healthy granulation tissue. In the present findings isolated organisms from the wound surface was identified as Staphylococcus aureus. This in line with previous findings that reported honey is effective bactericidal agent in controlling antibiotic resistant bacteria including $\mathrm{MRSA}^{40}$.

In the present study Honey exhibited antibacterial activity on the isolated bacteria which resulted in sterile wound. This in line with previous report that honey has been successfully used on infections not responding to standard antiseptics and antibiotics therapy, this criteria gives promising results in treating bacterial infections, such as ulcers, bed sore, burns, injuries and surgical wounds ${ }^{17}$.The findings of our study together with the previous one confirmed that Honey as wound dressing can be used to provide ideal environment for the rapid tissue repair and regeneration that are essential for growth of wound bed ${ }^{41}$. The inhibitory effects of honey may be useful against organisms which have developed resistance to many conventional treatment ${ }^{42}$. Recent 
study confirmed that honey is an effective substance in the management of wounds and may be used at any phase of wound healing ${ }^{43}$. Thus honey seems to accelerate wound healing by early promotion of healthy granulation tissue.

\section{Conclusion}

Daily application of honey on infected split skin graft wound with hypergranulation tissue gave favorable results. These involved clean sterile wound with healthy granulation tissue. Reduction of hypergranulation tissue to the wound level and accelerated wound healing in short duration without side effects.

Significance and Impact of Study: Honey can be used as alternative dressing to chronic wounds not responding to conventional treatment, it has been proved in surgical and plastic surgery unit at Khartoum North Hospital. This is attributed to its effectiveness in healing process of chronic infected wounds. Honey reduced wound with hypergranulation tissue without surgical interference. Thus honey may be a useful in granulation tissue promoter following surgical operations. Honey as natural product can be obtained easily with low cost, easy to apply and remove and more without side effects. Reduction of treatment duration resulted in shortening of hospitalization.

\section{Conflict of Interest}

The authors report no conflicts of interest.

\section{Role of Funding Source}

This research was funded by the Deanship of Scientific Research at Princess Nourah Bint Abdulrahman University through the Fast-track Research Funding Program.

\section{Ethical Approval}

Ethical approval was obtained from the Ethics Committee Khartoum North Teaching Hospital Surgery and Plastic Surgery Unit. Sudan. Written informed consent was obtained from the patient prior to the study.

\section{Acknowledgement}

This research was funded by the Deanship of Scientific Research at Princess Nourah Bint Abdulrahman University through the Fast-track Research Funding Program.

We also thank the team of plastic surgery unit Khartoum North Teaching Hospital, Sudan for their help.

\section{References}

1. Dunford C. Hypergranulation tissue. Journal of Wound Care. 1999; 8:506-7 https://doi.org/10.12968/jowc.1999.8.10.26222. PMid:10827655

2. Moody MN, Landau JM, Goldberg LH, Marquez D, Vergilis-K. 2011 IJ. $595 \mathrm{~nm}$ long pulsed dye laser with a hydrocolloid dressing for the treatment of hypergranulation tissue on the scalp in postsurgical defects. Dermatol Online Journal. 2011; 17:2.

3. Pokharel RP, Maeda K, Yamamoto T, Noguchi K, Iwai $\mathrm{Y}$, Nakamura $\mathrm{H}$, et al. Expression of vascular endothelial growth factor in exuberant tracheal granulation tissue in children. The Journal of pathology. 1999; 188:82-6. https:// doi.org/10.1002/(SICI)1096-9896(199905)188:1<82::AIDPATH324>3.0.CO;2-4

4. Vuolo J. Hypergranulation: Exploring possible management options. British Journal of Nursing. 2010; 19:S4,S6-S8. https:// doi.org/10.12968/bjon.2010.19.Sup2.47244. PMid:20335928

5. Young T. Common problems in wound care: Overgranulation. British Journal of Nursing. 1995; 4:169-70. https://doi. org/10.12968/bjon.1995.4.3.169

6. Falanga V, Zitelli JA, Eaglstein WH. Wound healing. The Journal of the American Academy of Dermatology. 1988; 19:559-63. https://doi.org/10.1016/S0190-9622(88)80317-7

7. Gethin G. The significance of surface $\mathrm{pH}$ in chronic wounds. Wounds UK. 2007; 3:52-6.

8. Singer AJ, Clark RA. Cutaneous wound healing. The New England Journal of Medicine. 1999; 341:738-46. https://doi. org/10.1056/NEJM199909023411006. PMid:10471461

9. Kaufman T, Berger J. Topical $\mathrm{pH}$ and burn wound healing: A review. Beyond occlusion: Wound care proceedings. Royal Society of Medicine Services Limited Israel. 1988:55-9.

10. Tsukada $\mathrm{K}$, Tokunaga $\mathrm{K}$, Iwama $\mathrm{T}$, Mishima $\mathrm{Y}$. The $\mathrm{pH}$ changes of pressure ulcers related to the healing process of wounds. Wounds. 1992; 4:16-20

11. Pokharel RP, Maeda K, Yamamoto T, Noguchi K, Iwai Y, Nakamura $\mathrm{H}$. Expression of vascular endothelial growth factor in exuberant tracheal granulation tissue in children. The Journal of Pathology. 1999; 188:82-6. https://doi. 
org/10.1002/(SICI)1096-9896(199905)188:1<82::AIDPATH324>3.0.CO;2-4

12. Gethin G, Cowman TS, Conroy RM. The impact of Manuka honey dressings on the surface $\mathrm{pH}$ of chronic wounds. International Wound Journal. 2008; 5:185-94. https://doi. org/10.1111/j.1742-481X.2007.00424.x. PMid:18494624

13. Wilson IA, Henry M, Quill RD, Byrne PJ. The $\mathrm{pH}$ of varicose ulcer surfaces and its relationship to healing. VASA. 1979; 8:339-42.

14. Romanelli M, Schipani E, Piaggesi A, Barachini P. Evaluation of surface ph on venous leg ulcers under Allevyn Dressings. London: Royal Society of Medicine Press; 1997.

15. Weller R, Price R, Ormerod A, Benjamin N, Leifert C. Antimicrobial effect of acidified nitrite on dermatophyte fungi, Candida and bacterial skin pathogens. Journal of Applied Microbiology. 2001; 90:648-52. https://doi.org/10.1046/j.13652672.2001.01291.x. PMid:11309079

16. Weller R, Finnen MJ. The effects of topical treatment with acidified nitrite on wound healing in normal and diabetic mice. Nitric Oxide - Biology and Chemistry. 2006; 15:395-9. https://doi.org/10.1016/j.niox.2006.04.002. PMid:16731016

17. Ahmed AK, Hoekstra MJ, Hage J, Karim RB. Honey-medicated dressing: Transformation of an ancient remedy into modern therapy. Annals of Plastic Surgery. 2003; 50:143-8.https://doi. org/10.1097/01.SAP.0000032306.44107.C1. PMid:12567050

18. AL-Hasani H, Hussein M. Study antibacterial activity of honey against some common species of pathogenic bacteria. Iraqi Journal of Science. 2018; 59(1A):30-7. https://doi. org/10.24996/ijs.2018.59.1A.5

19. Gill R, Poojar B, Bairy LK, Praveen KSE. Comparative evaluation of wound healing potential of manuka and acacia honey in diabetic and nondiabetic rats. Journal of Pharmacy and Bioallied Sciences. 2019; 11(2):116-26. https://doi.org/10.4103/JPBS.JPBS_257_18 PMid:31148887 PMCid:PMC6537647

20. Lusby PE, Coombes A, Wilkinson JM. Honey: A potent agent for wound healing? Journal of Wound, Ostomy and Continence Nursing. 2002; 29:295-300. https://doi.org/10.1097/00152192200211000-00008

21. Auguskani JPL. study to assess the chemical composition and antibacterial properties of honey. Biomedical Research. 2018; 29(19):3584-9. https://doi.org/10.4066/ biomedicalresearch.29-18-919

22. Mama M, Teshome T, Detamo J. Antibacterial activity of honey against methicillin-resistant staphylococcus aureus: A laboratory-based experimental study. International Journal of Microbiology. 2019:1-9. https://doi.org/10.1155/2019/7686130. PMid:31073310 PMCid:PMC6470442

23. Gill R, Poojar B, Bairy LK, Kumar SEP. Comparative evaluation of wound healing potential of manuka and acacia honey in diabetic and nondiabetic rats. Journal of Pharmacy and
Bioallied Sciences. 2019; 11(2):116-26. https://doi.org/10.4103/ JPBS.JPBS_257_18. PMid:31148887 PMCid:PMC6537647

24. Febriyenti F, Lucida H, Almahdy A, Alfikriyah I, Hanif M. Wound-healing effect of honey gel and film. Journal of Pharmacy and Bioallied Sciences. 2019 Apr-Jun; 11(2):176-80. https://doi.org/10.4103/JPBS.JPBS_184_18. PMid:31148895 PMCid:PMC6537643

25. Nasrin T, Abbas H, Gholamreza H, Rouini MR, Manayi A. Synergistic effect of honey and propolis on cutaneous wound healing in rats. Azadeh. Acta Medica Iranica. 2016; 54(4):2339.

26. Yang KL. The use of honey in the treatment of chilblains, nonspecific ulcers, and small wounds. Chinese Medical Journal. 1944; 62:55-60.

27. Subrahmanyam M. Honey dressing versus boiled potato peel in the treatment of burns: A prospective randomized study. Burns. 1996; 22(6):491-3. https://doi.org/10.1016/03054179(96)00007-1

28. Hananeh WM, Ismail ZB, Alshehabat MA, Mahmoud AA, Ali JH. Effects of Sidr honey on second-intention healing of contaminated full-thickness skin wounds in healthy dogs. Bulletin of the Veterinary Institute in Pulawy. 2015; 59(3):4339. https://doi.org/10.1515/bvip-2015-0063

29. Shaikh, Abdul Razaque; Ali, Syed Asad; Tahir, Syed Mohammad; Memon, Riaz; Memon, Abdul Salam. Role of Honey in Wounds Infected by MRSA in a Teaching Hospital. Annals of Pakistan Institute of Medical Sciences. 2016; 12(4):267-70.

30. Suryaprakash A, Tejaswini V, Girish K, Vikram S. Efficacy of honey dressing versus mechanical debridement in healing of ulcers with biofilms a comparative study. Journal of Krishna Institute of Medical Sciences University (JKIMSU). 2018 AprJun; 7(2):49-55.

31. Bauer AW, Kirby WM, Sherris JC, Turck M. Antibiotic susceptibility testing by a standardized single disk method. American Journal of Clinical Pathology. 1966 Apr; 45(4):4936. https://doi.org/10.1093/ajcp/45.4_ts.493. PMid:5325707

32. Garrod LP, Lambert HP, O'Grady F. Antibiotics and Chemotherapy. 5th ed. Churchill Livingstone, New York; 1988.

33. Liguori PA, Peters KL, Bowers JM. Combination of negative pressure wound therapy and acoustic pressure wound therapy for treatment of infected surgical wounds: A case series. Ostomy Wound Manage. 2008; 54(5):50-3.

34. Fukuda M, Kobayashi K, Hirono Y, Miyagawa M, Ishida T, Ejiogu EC. Jungle honey enhances immune function and antitumor activity. Evidence-Based Complementary and Alternative Medicine; 2011. https://doi.org/10.1093/ecam/ nen086. PMid:19141489. PMCid:PMC3137786

35. Molan PC. The evidence supporting the use of honey as a wound dressing. The International Journal of Lower Extremity Wounds. 2006; 5(1):40-54. https://doi.org/10.1177/1534734605286014. PMid:16543212 
36. Majtan J, Kumar P, Majtan T, Walls AF, Klaudiny J. Effect of honey and its major royal jelly protein 1 on cytokine and MMPmRNA transcripts in human keratinocytes. Experimental Dermatology. 2010; 19:e73-e9. https://doi.org/10.1111/j.16000625.2009.00994.x. PMid:19845754

37. Molan PC. The evidence and the rationale for the use of honey as a wound dressing. Wound Practice \& Research. 2011; 19:204-20.

38. Molan PC. The role of honey in the management of wounds. Journal of Wound Care. 1999; 8:415-18. https://doi. org/10.12968/jowc.1999.8.8.25904. PMid:10808853

39. Cavanagh D, Beazley J, Ostapowicz F. Radical operation for carcinoma of the vulva. A new approach to wound healing. Journal of Obstetrics and Gynaecology of the
British Commonwealth. 1970; 77:1037-1040. https://doi. org/10.1111/j.1471-0528.1970.tb03455.x. PMid:5483415

40. Nagi AA, Amghalia E, Shamsudin MN, Abdullah R, Mohammed R, Sekawi Z. Antibacterial activity of honey against methicillin resistant Staphylococcus aureus. Research Journal of Biological Sciences. 2009; 4(8):943-47.

41. Molan P, Rhodes T. Honey: A biological wound dressing. Wounds, 2015; 27(6):141-5.

42. Armstong S, Otis GW. The antibacterial properties of honey. Bee Culture. 1995; 123(9):500-50.

43. Vyhlídalová D, Kozáková R, Zeleníková R. Management of non-healing wounds with honey dressings. Central European Journal of Nursing and Midwifery. 2018; 9(3):880-8. https:// doi.org/10.15452/CEJNM.2018.09.0019 